\title{
POST - CRISIS EXCHANGE RATE POLICY IN INDONESIA
}

\author{
Abdul Hadi Ilman \\ Fakultas Ekonomi dan Bisnis Universitas Teknologi Sumbawa \\ abdul.ilman@gmail.com
}

\section{Introduction}

In 1997 Indonesia was hit by a severe financial crisis which led to the change of almost everything in the country, including the exchange rate regime; from managed floating to free floating or flexible exchange rate. It has been a major conclusion from academic debate that maintaining exchange rate at a certain level or band (soft peg) was no longer workable in the more integrated financial system, international market, and free flow of capital mobility across economy.

Indonesia once was known as one of the "Asian Tigers" which were believed to be the next industrialized economies as was being indicated by astounding macroeconomic performance since the early 1990s. The exchange rate management, in which the objective was to have a competitiveness in the international market, was making a huge contribution to that performance. No one suspected those countries would be hit by the crisis until Thailand's Bath was under attacked and suddenly it spread expeditiously to other economies.

Domestically, economy of Indonesia was funded by foreign debt in the several years before crisis to leverage the economy, especially private sector. Thus, when the currency crisis was happening, the value of rupiah was depreciated so much and the central bank could not afford to stabilize the value of rupiah in the market. Then a huge amount of the dollar-denominated short term debt was suspected to default since the debt value in rupiah was becoming very large.

The inability of central bank to maintain the value of rupiah by intervening the market had forced Indonesia to break the rule and change the exchange regime. It was too costly in many aspects to maintain the same regime. Then, since July 1997 the government of Indonesia announced to use the free (independently) floating exchange rate and let the market decide the appropriate value of rupiah. There were some expectations that free floating exchange rate will be giving more stable economy as whole and bringing an autonomous mechanism inside the regime to stabilize and balance the economy.

It has been 16 years the free floating exchange rate adopted by Indonesia and several complementary policies have been taken to support the objective of stabilization of rupiah. It is also clear that this free floating is not pure or clean; it is dirt in some degree. The matter then how dirty the free floating; how much the central bank is intervening the market. Meanwhile, there has been some economic shocks, either domestically and internationally, which were giving impacts in some extent to the exchange rate.

This paper has some objectives. First, through this paper it is very important to begin with the description of the policy changes, from managed floating exchange rate to free floating exchange rate after the crisis. Second, to analyze why this change was taken and how the new regime performs so far. Third, to formulate the policy implication for the future.

The post crisis period in this paper refers to July in 1997 when the new policy was announced formally by the government, until October 2013, the latest data available. During this period, it is inevitably there has been some economic circumstance that will be recognized throughout the paper. For instance, the global financial crisis in 2008, must had some impact in the exchange rate performance.

\section{Literature Review}

Which exchange rate regimes should be applied for which country has been remain the central debate among the economist for some decades. Some theoretical and empirical evidences have been proposed to argue and defend any of them. The conventional debate was 
whether to fix or let it free. But, the recent debate is growing to some extent in which not to choose the two extreme of them, due to the reality of no evidence of an economy that really applying the extreme point. No country adopt pure or clean floating exchange rate as well as it is hard to find a country with strictly fix its exchange rate. Each of economy has a certain degree of "dirty" in applying any exchange rate regime. Since then, the discussion has been moving to what degree can be accepted given some other economic and noneconomic indicators in a specific country.

Table 1. The Use of Exchange Rate Arrangements

\begin{tabular}{|c|c|c|c|c|c|c|c|c|}
\hline \multirow[b]{2}{*}{ Type of arrangement } & \multicolumn{2}{|c|}{$1960-73$} & \multicolumn{2}{|c|}{$1974-81$} & \multicolumn{2}{|c|}{$1982-88$} & \multicolumn{2}{|c|}{ 1989-94 } \\
\hline & \# of Obs & $\%$ & $\#$ of Obs & $\%$ & $\#$ of Obs & $\%$ & $\#$ of Obs & $\%$ \\
\hline $\begin{array}{l}\text { Fixed to single } \\
\text { currency }\end{array}$ & 322 & 88.5 & 159 & 76.4 & 110 & 60.4 & 56 & 35.9 \\
\hline Fixed to basket & & & & & 4 & 2.2 & & \\
\hline Fixed w/frequent adj. & 18 & 4.9 & 12 & 5.8 & 4 & 2.2 & 3 & 1.9 \\
\hline $\begin{array}{l}\text { Forward looking } \\
\text { crawling peg }\end{array}$ & & & 9 & 4.3 & 4 & 2.2 & 10 & 6.4 \\
\hline $\begin{array}{l}\text { Forward looking } \\
\text { crawling band }\end{array}$ & & & & & & & 6 & 3.8 \\
\hline $\begin{array}{l}\text { Backward looking } \\
\text { crawling peg }\end{array}$ & 12 & 3.3 & 22 & 10.6 & 46 & 25.3 & 12 & 7.7 \\
\hline $\begin{array}{l}\text { Backward looking } \\
\text { crawling band }\end{array}$ & & & & & & & 7 & 4.5 \\
\hline Dirty Floating & 8 & 2.2 & 6 & 2.9 & 5 & 2.7 & 22 & 14.1 \\
\hline Free Floating & 4 & 1.1 & & & 9 & 4.9 & 40 & 25.6 \\
\hline Total & 364 & 100.0 & 208 & 100.0 & 182 & 100.0 & 156 & 100.0 \\
\hline
\end{tabular}

Source: Frieden, Ghezzi, and Stein (2000)

Mundel ${ }^{1}$ classifies the exchange rate mechanisms into several ranking according to the degree of monetary integration:

1. Clean float (no intervention)

2. Dirty float (flexible rate with sporadic intervention)

3. Crawling peg (frequent mini devaluations), no adjustment mechanism

4. Adjustable peg (infrequent devaluation), no adjustment mechanism

5. Tablita system (crawling peg with partial adjustment)

6. Tablita system (crawling peg with automatic adjustment)

7. Fixed spot rates with semiautomatic adjustment mechanism (flexible forward rates)

8. Fixed spot exchange rates, automatic adjustment, irrevocable parity (fixed forward rate)

9. Fixed rates, automatic adjustment, fixed relationship between foreign exchange reserves and central bank money

${ }^{1}$ Robert A. Mundell. Exchange-Rate Arrangements in the Transition Economies. Balance of Payment, Exchange Rates, and Competitiveness in Transition Economies, ed. Mario I. Blejer and Marko Skreb. Kluer Academic Publishers. (Boston, 1999-118). 
10. Currency board system (100 percent reserves backing central bank money)

11. Monetary union (common central bank)

12. Common currency (monetary union plus a common currency)

While Mundel is categorizing in the context of monetary union and currency union (which is the "highest" degree of fixing), Frieden, Ghezzi, and Stein ${ }^{2}$ have identified the exchange rate arrangement into similar classification and historically divide into 4 periods of time, as table 1

In July 2006 IMF also has classified into several regimes based on the actual, de facto, exchange rate arrangement applied by its members. ${ }^{3}$

Table 2. IMF Classification of de facto Exchange Rate Arrangements

\begin{tabular}{|c|l|c|c|}
\hline No & \multicolumn{1}{|c|}{ Exchange Rate Arrangements } & Number of Country & Percentage \\
\hline 1 & $\begin{array}{l}\text { exchange arrangement with no separate legal } \\
\text { tender }\end{array}$ & 41 & $22 \%$ \\
\hline 2 & currency board arrangements & 7 & $4 \%$ \\
\hline 3 & conventional fixed peg arrangements & 52 & $28 \%$ \\
\hline 4 & pegged exchange rates within horizontal bands & 5 & $3 \%$ \\
\hline 5 & crawling pegs & - & $3 \%$ \\
\hline 6 & exchange rate within crawling bands & 51 & $0 \%$ \\
\hline 7 & $\begin{array}{l}\text { managed floating with no predetermined path for } \\
\text { the exchange rate }\end{array}$ & 25 & $13 \%$ \\
\hline 8 & independently floating & & \\
\hline
\end{tabular}

Source: International Monetary Fund 2006.

All of those data suggest that over time more countries have adopted the exchange rate arrangement that close to free floating system, but a significant number of countries are still using the system that close to fixed exchange rate.

The data from IMF is based on the actual application of the exchange rate regime, instead of a system that has been announced by a country. It is possible that the implementation is different with the commitment at the beginning. For example A country can decide to use an independent free floating which is explicitly announced to the public, but for some reasons, in the reality there are some intervention into the market. Hernandez and Montiel ${ }^{4}$ argue there are several objectives for a developing country to have a different $d e$ facto exchange rate arrangement with de jure: 1) fear of volatility; 2) stabilization of the nominal effective exchange rate; 3 ), stabilization of the real effective exchange rate. 4), fear of depreciation. 5), fear of appreciation. 6), accumulation of a reserve "war chest."

The fact that there are still many countries using the dirtier to fixed exchange rate, is suggesting that the system still has some advantages to offer. There are two major argument in favor of fixed exchange rate of hard pegs, as mentioned by Velasco. ${ }^{5}$ The first argument is the credibility of monetary policy at home. If an economy has not enough credibility to execute its own monetary policy, pegging the home currency to any hard-money country with more credible monetary policy will enable to import its credibility to home. The second argument is the discipline argument which is saying that pegging exchange rate will encourage fiscal or monetary authority to be more

\footnotetext{
2 Jeffry Frieden, Piero Ghezzi, and Ernesto Stein. Politics and Exchange Rate in Latin America. Research Network Working Paper \#R-42 I. Inter-American Development Bank. (Washington, 2000)

3IMF. De Facto Classification of Exchange Rate and Monetary Framework.

http://www.imf.org/external/np/mfd/er/2006/eng/0706.htm

${ }^{4}$ Leonardo Hernandez and Peter J. Montiel. Post-Crisis Exchange Rate Policy in Five Asian Countries: Filling in the "Hollow Middle'? Paper for High Level Seminar "Exchange Rate Regimes: Hard Peg or Free Floating", IMF Institute. (Washington, 2001).

${ }^{5}$ Andres Velasco. Exchange Rate Policies for Developing Countries: What Have We Learned? What Do We Still Not Know? G-24 Discussion Paper No.5. United Nation. (New York, 2000).
} 
discipline, since any eventual collapse in the exchange rate would have a big impact on political aspect. Moreover, Garber and Svenson ${ }^{6}$ say that a fixed exchange rate could help to minimize instability in the real economic activities.

But the fixed exchange rate also have some disadvantages, which sometimes come from its strength. For instance, pegging a currency lies in the absence of escape clause. In some cases it provides advantages, but more disadvantages will come if the political cost of abandoning the peg is not large enough to prevent it to be happened. In other side, if successfully abandoned, expected inflation and interest spreads can come down sharply. And about the need of discipline in applying fixed exchange rate due to the fear of impact from imprudent behavior, some argue that in case of free floating exchange rate those impact will be greater and can be transmitted immediately through the movement of exchange rate and price level. It means that fixed exchange rate does not provide the stronger tool to force the monetary and fiscal authority discipline. ${ }^{7}$

To make the fixed exchange rate works well is not easy, there are some requirements need be met, which are known as Mundell-McKinnon optimal currency area theory: 1) symmetric real shocks; 2) trade with anchor currency; 3) flexible labor market; 4) sound, wellcapitalized, and well regulated banking system; 4) small countries with weak monetary and fiscal institution. ${ }^{8}$

In case of free floating exchange rate, as Friedman ${ }^{9}$ argues the main advantage is if there is a shock that need adjustment in the real exchange rate, it will be faster and less costly to move the nominal exchange rate, in case of prices move slowly. This works well in the countries that often have a large shock from abroad. As Mundell also says, "If shocks to the good markets are more prevalent than shocks to the money market, then a flexible exchange rate is preferable to a fixed rate." 10

Some objections to the flexible exchange rate have been raised, since the prevalence of wage indexation (Hausmann et al.) ${ }^{11}$, high degree of pass through may prevent real exchange rate adjustment, and the problem with the lack of credibility of the monetary policy.

Weather fixed exchange rate or free floating exchange rate is the best for an economy, is still not clear and hugely depending on many factors. However, generally the optimal exchange rate regime is a managed float system as pointed out by Genberg. ${ }^{12}$ This is because in the managed float exchange rate system, money supply will react to exchange rate, interest rate, and other economic indicators. IMF published some considerations need to think of when deciding the appropriate exchange rate management:

\begin{tabular}{ll}
\hline Characteristic of Economy & $\begin{array}{l}\text { Implication for the Desired Degree of Exchange Rate } \\
\text { Flexibility }\end{array}$ \\
\hline Size of economy & $\begin{array}{l}\text { The larger the economy, the stronger is the case for a } \\
\text { flexible rate }\end{array}$ \\
\hline openness & $\begin{array}{l}\text { The more open the economy, the less attractive is a flexible } \\
\text { exchange rate }\end{array}$ \\
\hline Diversified production/export structure & $\begin{array}{l}\text { The more diversified the economy, the more feasible is a } \\
\text { flexible exchange rate }\end{array}$ \\
\hline
\end{tabular}

\footnotetext{
${ }^{6}$ Peter M. Garber and Lars E.O Svenson. The Operation and Collapse of Fixed Exchange Rate Regimes. NBER Working Paper No. 4971. (Cambridge, 1994)

${ }^{7}$ Andres Velasco. Exchange Rate Policies for Developing Countries: What Have We Learned? What Do We Still Not Know? G-24 Discussion Paper No.5. United Nation. (New York, 2000).
}

\author{
8 Ibid. \\ 9 Ibid. \\ 10 Ibid. \\ 11 Ibid. \\ 12 Genberg (1989) in Peter M. Garber and Lars \\ E.O Svenson. The Operation and Collapse of Fixed \\ Exchange Rate Regimes. NBER Working Paper \\ No. 4971. (Cambridge, 1994)
}




\begin{tabular}{|c|c|}
\hline Geographic concentration of trade & $\begin{array}{l}\text { The larger the proportion of an economy's trade with one } \\
\text { large economy, the greater is the incentive to peg to the } \\
\text { currency of that country }\end{array}$ \\
\hline $\begin{array}{l}\text { Divergence of domestic inflation from } \\
\text { world inflation }\end{array}$ & $\begin{array}{l}\text { The more divergent a country's inflation rate from that of its } \\
\text { main trading partners, the greater is the need for frequent } \\
\text { exchange rate adjustments.(But for a country with } \\
\text { extremely high inflation, a fixed exchange rate may provide } \\
\text { greater policy discipline and credibility to a stabilization } \\
\text { program) }\end{array}$ \\
\hline $\begin{array}{l}\text { Degree of economic/financial } \\
\text { development }\end{array}$ & $\begin{array}{l}\text { The greater the degree of economic and financial } \\
\text { development, the more feasible is a flexible exchange rate } \\
\text { regime }\end{array}$ \\
\hline Labor mobility & $\begin{array}{l}\text { The greater the degree of labor mobility, when wages prices } \\
\text { are downwardly sticky, the less difficult (and costly) is the } \\
\text { adjustment to external shocks with a fixed exchange rate }\end{array}$ \\
\hline Capital mobility & $\begin{array}{l}\text { The higher the degree of capital mobility, the more difficult } \\
\text { it is to sustain a pegged-but-adjustable exchange rate }\end{array}$ \\
\hline Foreign nominal shocks & $\begin{array}{l}\text { The more prevalent the foreign nominal shocks, the more } \\
\text { desirable is a flexible exchange rate }\end{array}$ \\
\hline Domestic nominal shocks & $\begin{array}{l}\text { The more prevalent the domestic nominal shocks, the more } \\
\text { attractive is a fixed exchange rate }\end{array}$ \\
\hline Real shocks & $\begin{array}{l}\text { The greater an economy's susceptibility to real shocks, } \\
\text { whether foreign or domestic, the more advantageous is a } \\
\text { flexible exchange rate }\end{array}$ \\
\hline Credibility of policymakers & $\begin{array}{l}\text { The lower the anti-inflation credibility of policymakers, the } \\
\text { greater is the attractiveness of a fixed exchange rate as } \\
\text { nominal anchor }\end{array}$ \\
\hline
\end{tabular}

Source: Rana (1998) 13

Based on Velasco, ${ }^{14}$ the implementation of any exchange rate regime requires some complementary policies to have a successful objectives. This strongly applies especially to the flexible exchange rate. These complementary regulation can be capital control, prudential regulation in the financial system, and counter-cyclical fiscal policy.

\section{Description of the Policy Change}

A free floating exchange rate arrangement have been officially adopted by Indonesia since August $14^{\text {th }}$, 1997. The system adopted after the country was hit by the biggest financial crisis in Indonesia. Previously, a fixed exchange rate was used in 1970 to 1978 and managed floating exchange rate was implemented since 1978 until August 1997.

Under the fixed exchange rate in 1970, Indonesia pegged the value of rupiah to US dollar and had a multiple exchange rate structure which were consist of a Flexible General Exchange (DU) Rate, a Flexible Credit Foreign Exchange (DK) Rate, and Export Rate. At that time, Indonesia also began to liberalize its capital account by removal of compulsory of export proceeds. After continuing devaluation of rupiah because of US Dollar's floating, in 1987 Bank Indonesia overthrown the DK rate and introduced an Effective Rate under the managed floating exchange rate. The bands of the rate was determined based on a basket of currencies of Indonesia's main trading partners.

In the early 1990s, the band of the currency fluctuation had been widened for several times to make it more flexible and adjusting to the real value. The first change was taken in 1994, a spread of plus or minus Rp15. And then was followed in in 1995 (Rp22), June 1996 (Rp118 or 5\%), September 1996 (Rp119 or $8 \%)$, and in July 1997 (12\%). (More detail about the exchange rate policies before the crisis in the appendix).

13 Pradumna B. Rana. The East Asian Financial Crisis-Implication for Exchange Rate Management. Economics and Development Resources Center Briefing Notes No.5, Asian Development Bank. 1998. ${ }^{14}$ Andres Velasco. Exchange Rate Policies for Developing Countries: What Have We Learned? What Do We Still Not Know? G-24 Discussion Paper No.5. United Nation. (New York, 2000) 
The adoption of any exchange rate regime mostly depends on the condition of a country at specific of time and need other complementary policies. Therefore, Bank Indonesia as the monetary authority considered to adopt the free floating exchange rate when the crisis was attacking the Indonesia's rupiah. The logical consequence then a monetary policy anchor was not the exchange rate anymore and Bank Indonesia decide to target the money base operationally during the IMF stabilization period. But, using money base as target had some difficulties and poorly transmit to the market led to fail to maintain market expectation on the future exchange rate movement.

Since 2005, Bank Indonesia adopted an inflation targeting framework which has three main characteristics: 1) monetary policy is directed to achieve a target of inflation for a specified time horizon which is explicitly announced to the public by central bank; 2) inflation targeting is working on a forward-looking basis by responding the development of inflation for the future trend; 3) the implementation of monetary policy must be transparent and accountable to ensure the credibility of the policy..$^{15}$

The next paragraphs will be explaining the other complementary policies was taken by Indonesia after adopting the flexible exchange rate in 1997, including capital control, financial system regulation, and counter cyclical fiscal policy.

During the IMF stabilization period from 1997 to 2003, Indonesia was restricted to introduce any capital management or measure since IMF program requires a client country to deregulate some policies and being more open to international exposure. There was found only one policy that represent to capital control during that period, which was in 2001 Indonesia prohibited trading by domestic bank: (i) rupiah denominated overdraft; (ii) lending to non-residents; (iii) transactions or rupiah-denominated bonds issued by non-residents; (iv) rupiah trading among non-residents; (v) investment in stocks issued by non-residents in rupiah currency.

Since then, there are several policies have been taken, as follows ${ }^{16}$ :

- 2004: strict regulation on the reserves in rupiah in bank accounts

- 2004: reporting required for offshore borrowings by financial institutions

- 2005: short-term borrowings to be less than $30 \%$ of total assets: central bank's approval required for longterm external borrowings

- 2005: reserve requirement in Bank Indonesia account raised

- 2006: transfer of rupiah currency to non-residents prohibited

- 2008: requirement of repot to the authority on external borrowings from non-residents

- 2008: ceiling of conversion of rupiah to foreign exchange for nonresidents over $\$ 100,000$ monthly (requirement of special approval for over $\$ 100,000$ )

- 2008: conversion of rupiah to foreign currency limited for current account transactions in principle

- 2010: requirement of holding SBI (Central Bank securities) more than 1 month

- 2011: bank's offshore short-term borrowing up to $30 \%$ of capital

- 2011: reserve requirement of 5 percent of total foreign-exchange holdings for banks

- 2011: all transactions of bank are to be used by rupiah 
The policy of financial system stability after 1997 crisis is aiming to regain public confidence toward the banking and other financial sectors. In doing so, Bank Indonesia has been pursuing the long-term financial stability and improving the intermediary function of financial system. As mentioned by Goeltom ${ }^{17}$, the following are actions were taken:

i) Reestablish confidence in the

financial sector by allowing a

blanket guarantee scheme for all depositors, either in domestic and foreign currency.

ii) Improve the internal governance of banks

a. Strengthening of the legal

framework, policies and

infrastructure of the banking

system. Indonesia has new laws on

the banking system and the central

bank since 1998 and 1999

respectively.

b. Strengthening of prudential regulations.

iii) Rebuilding bank solvency

a. Establishment of the Indonesian

Banking Restructuring Agency

(IBRA) and the asset Management Unit (AMU).

b. Closing-down of problem banks.

c. Strengthening of bank capital.

The most recent important policy in Indonesia's financial system is the unification of financial supervisory agency into a single authority. Previously, banking system was supervised by Bank Indonesia as a central bank, and other financial system including capital stock market, insurance, and other financial institution were supervised by BAPEPAM-LK under the Ministry of Finance. The new agency is Financial Service Authority (Otoritas Jasa Keuangan, OJK) has the responsibility in the micro prudential aspect of financial system, while the macro prudential still will be under Bank Indonesia's supervision.

17 Miranda S. Goeltom. Capital Flows in Indonesia: Challenges and Policy Responses.
In the fiscal aspect, the government has embarked on two steps in strengthening the fiscal prudence. First, reduce the size of foreign debt by promoting fiscal surplus and revenue from state-owned enterprises privatization. Second, relieve the government dependency on international borrowing by reducing government expenditure on investment and consumption. Fiscal policy at the crisis period was aiming to promote economic recovery and establish a strong fundamental for sustainable fiscal management. ${ }^{18}$

\section{Analysis and Explanation \\ Why the exchange rate regime changes did take place?}

In one side, a successful economic performance in Indonesia and other Asian countries in early 1990s had invited many foreign investment. And in another side many industrial economies was having a bad performance at the same time. This led capital to flow to these Asian emerging market. The shortterm inflows were quite substantial to make an impact when there was a sudden reversal in the capital market. Central bank could not afford to intervene more under the managed floating exchange rate. The cost to maintain the band was too large, and eventually central bank adopted the flexible exchange rate.

Since 1970, Indonesia had liberalized its economy and was becoming more open to international financial system which was getting more integrated between countries. The consequences of this openness was Indonesia has recorded a financial account surplus from that period until before crisis in 1997. The average financial account surplus from year 1980 to 1996 was USD4,886 million per year. The most problematic was the increasing of net capital flows into private sector, while at the same time net

Bank of International Settlement Papers No. 44.

(Geneva).

18 Ibid. 
capital flows to government was decreasing (see the table below).

\section{Net capital flows}

In millions of US dollars

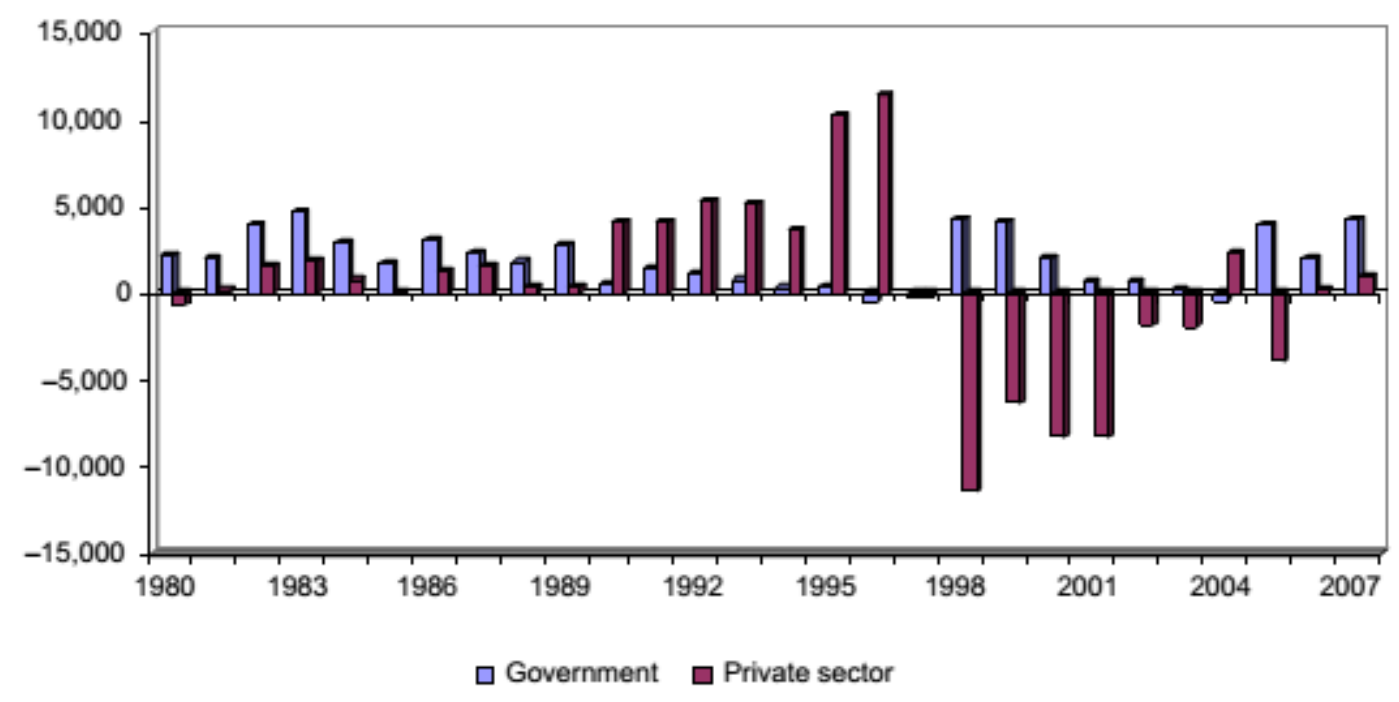

Source: Bank Indonesia.

This massive capital flow was also supported by the weak performance of industrialized economies which was led to accommodative monetary policies, abundant liquidity, and low interest rate, and rise in stock market. All of them were reducing the asset yield in those industrial countries and made the emerging market, especially Asian market, an increasingly attractive investment opportunity. The graphs below are showing the yield spread in Europe and Asia countries.

\section{Secondary Market Yield Spreads on U.S. Dollar-Denominated Eurobonds1}

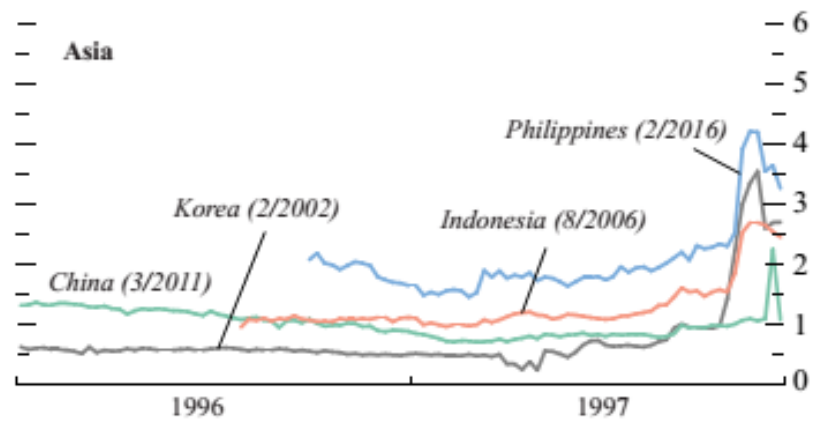

(In percent a year)

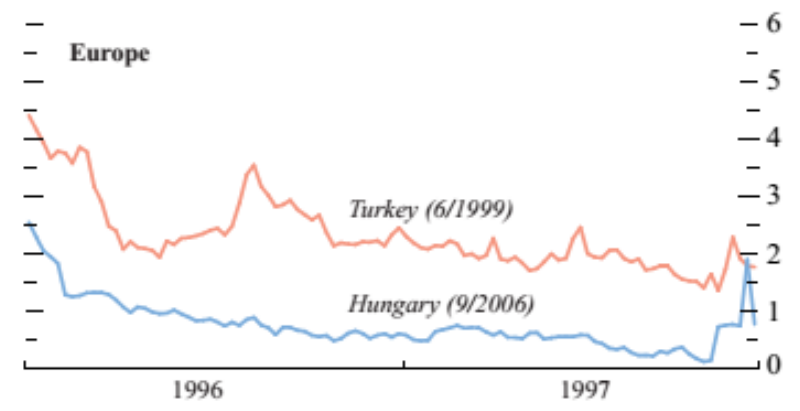

The central bank was forced to widen the intervention band in response to outof-control capital inflows into the economy. This policy was aiming to send a signal to the 
market in predicting future movement in the nominal exchange rate. But, the amount of capital inflows was too large and always drive the nominal exchange rate to the bottom of limit of the decided intervention band (see graph below).

Exchange rate movement and the intervention band

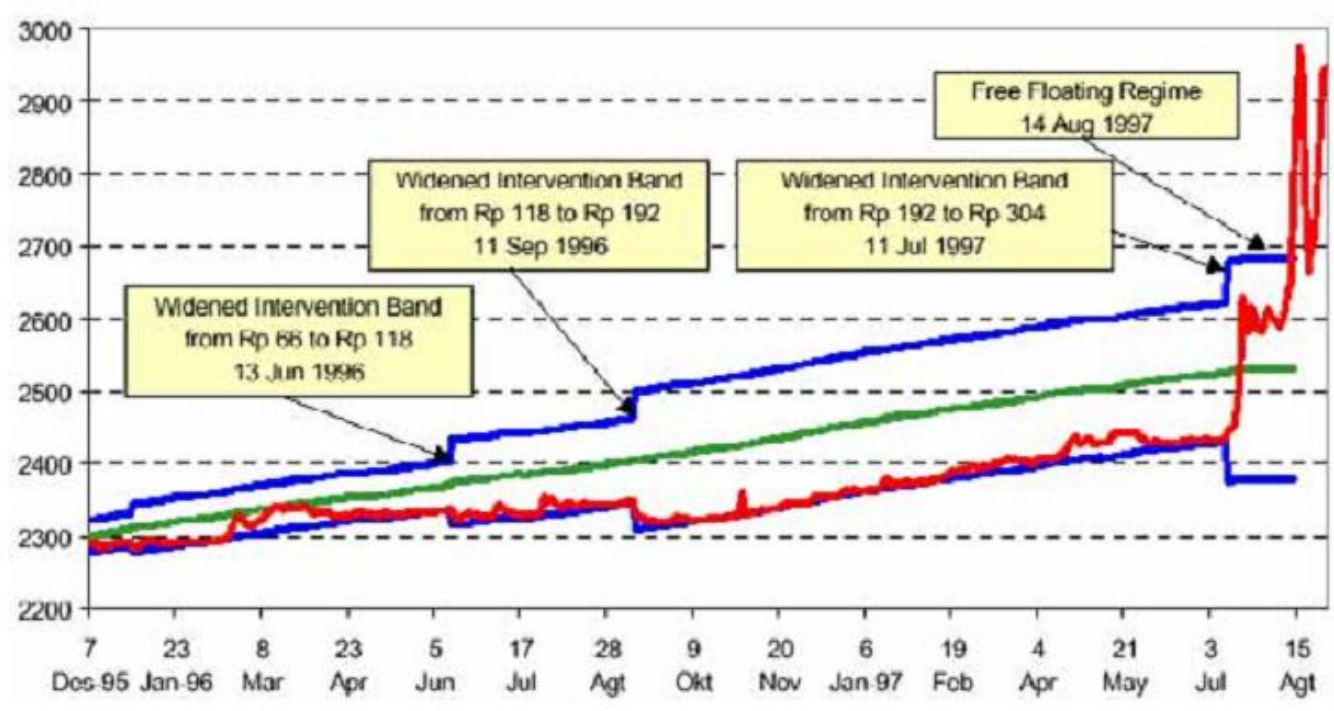

Source: Bank Indonesia.

When the Thailand's currency crisis started to spill over to Indonesia, there was a massive sudden reversal of capital, the managed floating exchange rate regime was under problem because the market intervention will be hugely expensive, monetary sterilization was becoming less effective and also increase the quasi-fiscal cost of monetary policy operations. Widening to intervention band was not enough and the eventually central bank decided to adopt the flexible exchange rate on August 14, 1997.

\section{How well the policies has been worked?}

Almost all countries who adopting de jure free exchange rate system actually do not eliminate the intervention policy to maintain the stability of exchange rate. ${ }^{19}$ The intervention are carried on both through intervention in the foreign exchange market directly or indirectly by using the interest rate channel. That's why there are some gap between de jure and de facto exchange rate regime. In the recent literature there has been growing the methodology to identify such a gap based on the outcomes in the exchange rate, foreign exchange reserves, and domestic interest rate fluctuations. As suggested by Hernandez and Montiel 20 a fixed bilateral peg would exhibit no exchange rate variation outside a very narrow band (conventionally taken as $+/-2.25$ percent). In this part, I am going to refers to the research have been done by Hernandez \& Montiel (2001) and Calvo \& Rainhart $(2000)^{21}$ for the case of Indonesia.

Exchange rate volatility

\footnotetext{
${ }^{19}$ As posited by Calvo and Rainhart in Burhanudin Abdullah, Monetary and Exchange Rate Policy in a Global Financial Integration-Indonesia Experience. Paper presented at the South East Asia-Latin America and Caribbean Countries (SEACEN-LAC) Governors Seminar. (Kuala Lumpur, 2006).

${ }^{20}$ Leonardo Hernandez and Peter J. Montiel. Post-Crisis Exchange Rate Policy in Five Asian Countries: Filling in the "Hollow Middle'? Paper for High Level Seminar "Exchange Rate Regimes: Hard Peg or Free Floating", IMF Institute. (Washington, 2001).

${ }^{21}$ Ibid.
} 


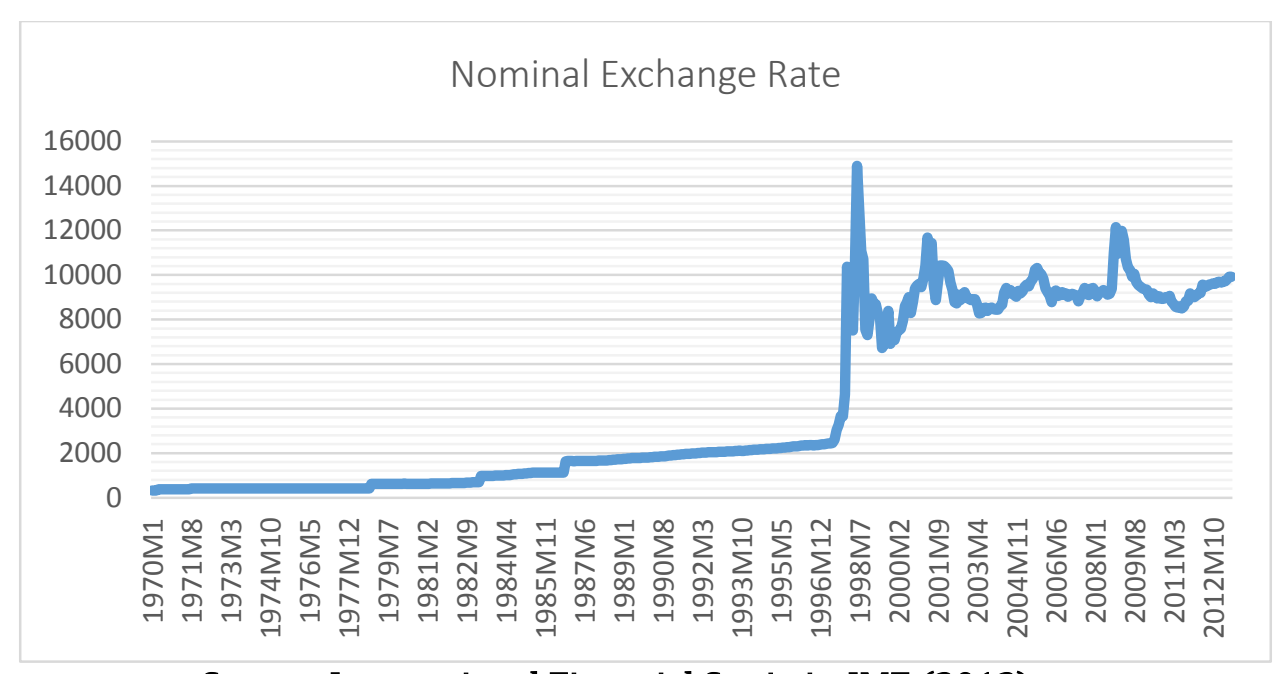

Source: International Financial Statistic, IMF (2013)

In the figure above is showing the nominal exchange rate of rupiah against US dollar, for both before and after crisis. Graphically, we can easily understand the comparison of movement of rupiah before and after crisis. More fluctuation of course can be seen after the crisis period.

The following table is the summary of Hernandez and Calvo \& Reinhart's research on monthly fluctuation of exchange rate before and after the Asian Crisis for case of Indonesia and compare to the countries with more clear floating exchange rate:

\section{Monthly Fluctuations in Exchange Rate}

\begin{tabular}{|c|c|c|c|c|c|c|}
\hline \multirow[b]{2}{*}{ Country } & \multicolumn{3}{|c|}{ Hernandez and Montiel } & \multicolumn{3}{|c|}{ Calvo and Reinhart } \\
\hline & Period & Range & Std. Dev & Period & $\begin{array}{c}+/-1 \% \\
\text { band }\end{array}$ & $\begin{array}{c}+/-2.5 \% \\
\text { band }\end{array}$ \\
\hline \multirow{2}{*}{ U.S. \$/DM } & Aug 95 - Jun 97 & 0.083 & 0.024 & \multirow{2}{*}{$\begin{array}{c}\text { Feb } 73- \\
\text { Apr } 99\end{array}$} & \multirow{2}{*}{26.8} & \multirow{2}{*}{58.7} \\
\hline & Jan $99-$ Nov 00 & 0.078 & 0.021 & & & \\
\hline \multirow{2}{*}{ U.S. \$/Yen } & Aug 95 - Jun 97 & 0.147 & 0.030 & \multirow{2}{*}{$\begin{array}{c}\text { Feb } 73- \\
\text { Apr } 99\end{array}$} & \multirow{2}{*}{33.8} & \multirow{2}{*}{61.2} \\
\hline & Jan $99-$ Nov 00 & 0.084 & 0.028 & & & \\
\hline \multirow{2}{*}{ Indonesia } & Aug 95 - Jun 97 & 0.033 & 0.007 & $\begin{array}{l}\text { Nov } 78- \\
\text { Jun } 97\end{array}$ & 96.4 & 99.1 \\
\hline & Jan 99 - Nov 00 & 0.230 & 0.063 & $\begin{array}{c}\text { Jul } 97-\text { Apr } \\
99\end{array}$ & 9.5 & 14.3 \\
\hline
\end{tabular}

Based on the Hernandez and Montiel's research, before the crisis Indonesia had more stable exchange rate compare to the clean floaters (the US, Germany, and Japan). It suggests that Indonesia actively defended the exchange rate of rupiah against US dollar. This conclusion is clear since in that period Indonesia was adopting the managed free floating exchange rate. In the post-crisis period, when Indonesia had adopted the flexible exchange rate, it was confirmed that the exchange rate of rupiah against US dollar was much more volatile than the clean floaters. From the table obviously shows the difference of range before and after crisis period is quite substantial. From this point of view, we can say that Indonesia have become "clean" floaters.

While from the research of Calvo and Reinhart, it suggested that Indonesia pegged its exchange rate and intervened so heavily in the pre-crisis period. But, it was changed after the crisis, when Indonesia have intervene so much less than before the crisis. They concluded then that Indonesia has been successfully transformed from "fixers" to "floaters'.

\section{Exchange reserve volatility}

The next indicator of exchange rate policy is the exchange reserves fluctuations. Central banking intervenes the foreign exchange market using the stock of exchange 
reserves. By analyzing the fluctuation in exchange reserve stocks volatility, we will get the indication of how much central bank intervening the market. When the stock of exchange reserves are stable over period of time, we might expect that central banking is allowing the foreign exchange to absorb the impact of shocks. Otherwise, central banking is still controlling the market too much. The following table is showing its measurement using mean absolute change and standard deviation in Hernandez and Montiel's research and plus minus 1 and 2.5 percent of band in the research done by Calvo and Reihart.

Monthly Fluctuations in Exchange Reserves

\begin{tabular}{|c|c|c|c|c|c|c|}
\hline \multirow[b]{2}{*}{ Country } & \multicolumn{3}{|c|}{ Hernandez and Montiel } & \multicolumn{3}{|c|}{ Calvo and Reinhart } \\
\hline & Period & $\begin{array}{c}\text { Mean } \\
\text { Absolute } \\
\text { Change }\end{array}$ & Std. Dev & Period & $\begin{array}{c}+/-1 \% \\
\text { band }\end{array}$ & $\begin{array}{c}+/-2.5 \% \\
\text { band }\end{array}$ \\
\hline U.S & & & & $\begin{array}{c}\text { Feb } 73- \\
\text { Apr } 99\end{array}$ & 26.8 & 62.2 \\
\hline \multirow{2}{*}{ Germany } & Aug 95 - Jun 97 & 1.082 & 1.325 & & & \\
\hline & Jan $99-$ Nov 00 & 1.225 & 1.535 & & & \\
\hline \multirow{2}{*}{ Japan } & Aug 95 - Jun 97 & 1.488 & 2.469 & \multirow{2}{*}{$\begin{array}{c}\text { Feb } 73- \\
\text { Apr } 99\end{array}$} & \multirow{2}{*}{44.8} & \multirow{2}{*}{74.3} \\
\hline & Jan $99-$ Nov 00 & 2.193 & 2.948 & & & \\
\hline \multirow{2}{*}{ Indonesia } & Aug 95 - Jun 97 & 2.038 & 2.892 & $\begin{array}{c}\text { Nov } 78- \\
\text { Jun } 97 \\
\end{array}$ & 22.8 & 41.5 \\
\hline & Jan 99 - Nov 00 & 3.169 & 5.335 & $\begin{array}{c}\text { Jul } 97-\text { Apr } \\
99\end{array}$ & 10 & 29.9 \\
\hline
\end{tabular}

In case of Hernandez and Montiel found exchange reserve volatility increased after the crisis as the mean absolute change was 3.169, from 2.038 in the pre-crisis period. It means that central bank had been intervening a lot in the market. This result is not consistent with the adoption of the flexible exchange rate regime which requires less (or no) intervention from the central bank. They argued that the assumption of a uniform volatility shocks is likely to have been violated in the case of Indonesia.

The methodology used by Calvo and Reinhart is suggesting that for floaters a high percentage of reserve changes should be contained within narrow band. In the case of Indonesia, the same surprising result was also found where the exchange reserve seems to be more fluctuate after the crisis than before.

\section{Domestic interest rate volatility}

Monthly Fluctuations in Nominal Interest Rate

\begin{tabular}{|c|c|c|c|c|c|c|c|c|c|}
\hline \multirow[b]{2}{*}{ Country } & \multicolumn{4}{|c|}{ Hernandez and Montiel } & \multicolumn{5}{|c|}{ Calvo and Reinhart (basis point) } \\
\hline & Period & Range & $\begin{array}{l}\text { Mean Absolute } \\
\text { Change }\end{array}$ & $\begin{array}{l}\text { Std. } \\
\text { Dev }\end{array}$ & Period & $\begin{array}{l}< \\
25\end{array}$ & $\begin{array}{l}< \\
50\end{array}$ & ${ }_{400}^{>}$ & $\underset{500}{>}$ \\
\hline U.S & & & & & $\begin{array}{c}\text { Feb } 73- \\
\text { Apr } 99\end{array}$ & 59.7 & 80.7 & 0.3 & 0.3 \\
\hline \multirow{2}{*}{$\begin{array}{c}\text { German } \\
\mathrm{y}\end{array}$} & $\begin{array}{l}\text { Aug } 95- \\
\text { Jun } 97\end{array}$ & 0.53 & 0.08 & 0.12 & & & & & \\
\hline & $\begin{array}{l}\text { Jan } 99- \\
\text { Nov } 00\end{array}$ & 0.68 & 0.13 & 0.16 & & & & & \\
\hline \multirow{2}{*}{ Japan } & $\begin{array}{c}\text { Aug } 95- \\
\text { Jun } 97\end{array}$ & 0.34 & 0.03 & 0.07 & \multirow{2}{*}{$\begin{array}{c}\text { Feb } 73- \\
\text { Apr } 99\end{array}$} & \multirow{2}{*}{67.9} & \multirow{2}{*}{86.4} & \multirow{2}{*}{0} & \multirow{2}{*}{0} \\
\hline & $\begin{array}{l}\text { Jan } 99- \\
\text { Nov } 00\end{array}$ & 0.27 & 0.02 & 0.05 & & & & & \\
\hline \multirow{2}{*}{$\begin{array}{c}\text { Indonesi } \\
\mathrm{a}\end{array}$} & $\begin{array}{l}\text { Aug } 95- \\
\text { Jun } 97\end{array}$ & 4.97 & 0.87 & 1.21 & $\begin{array}{c}\text { Nov } 78- \\
\text { Jun } 97\end{array}$ & 30.6 & 46.8 & 5.2 & 4 \\
\hline & $\begin{array}{c}\text { Jan } 99- \\
\text { Nov } 00\end{array}$ & 12.19 & 2.01 & 3.12 & $\begin{array}{l}\text { Jul } 97 \text { - } \\
\text { Apr } 99 \\
\end{array}$ & 0 & 0 & 75 & 70.1 \\
\hline
\end{tabular}

The final indicator is fluctuation of the domestic interest rate. The more fluctuate exchange rate would be associated with smaller fluctuation in the domestic interest rate, 
under assumption of the uniformity of shocks across countries and over time, and also that shock arise from credibility effects. For this analysis, Hernandez and Montiel are measuring in term of range of monthly fluctuation, its mean absolute change, and its standard deviations. While Calvo and Reinhart are using basis point fluctuations.

From both research, the important finding is interest rate volatility increased in the post-crisis period for Indonesia, suggesting that period has not a tranquil one in the exchange market.

Exchange Rate policy under Inflation Targeting Framework and its effectiveness

Since the adoption of inflation targeting framework, the main objective of monetary is to achieve the inflation target. Any monetary policy related to exchange rate is aiming to support and part of the whole such a monetary framework. Exchange rate movement in Indonesia does not always represent the fundamental value of rupiah, especially during the financial crisis 2008 when there were massive capital inflow form developed countries. Excessive exchange rate movement has significant impact on domestic economy including financial stability, so interest rate policy is not enough to manage the exchange rate volatility.

Therefore, exchange rate policy (intervention) must be part of the whole monetary policy framework in achieving price stability. There are five policy instrument: 1) interenst rate policy; 2) exchange rate policy; 3 ) management of capital flows; 4) macro prudential policy; 5) monetary policy communication. The objective of the exchange rate policy itself is to stabilize the exchange rate along its fundamental and it more support the price stability and financial system stability than to maintain external competitiveness. Operationally, there are three steps need to be taken: 1) develop a methodology to assess the exchange rate fundamental and its determining factor; 2) simulate the factors to assess its consistency; 3 ) make the decision of exchange rate policy that consistent with the objective of the inflation target. ${ }^{22}$

To conduct the exchange rate intervention, according to Warjiyo there are aspect need to be considered. First, the types of international investors; hedge fund (usually short term) or long term investors. The short term investors tend to create exchange rate volatility while the long run investors are more stable. Second, the determining factors that affect changes in international investors' behavior. Based on these two consideration, central bank is focusing on to provide a climate that is attractive to long-term investors to stabilize the exchange rate along its fundamental. In the operational level, the intervention is conducted through agent banks to buy and sell foreign currency (most US dollar) depending on excess supply or demand condition in the market.

The effectiveness of exchange rate intervention must be in line with the monetary policy objective in maintaining price stability. In the medium to long term, Indonesia is able to manage the volatility of exchange rate and ensure a path that is consistent with the price stability objective. This is reflected by the depreciation of rupiah from 2008 to 2011, reflecting the overall macroeconomic developments during the period. In the short term, the effectiveness of the policy is hugely depending on the credibility of communication by central bank to influence market expectation on exchange rate and inflation. ${ }^{23}$

\section{Implication}

There some policy recommendation need to be considered

\footnotetext{
22 Perry Warjiyo. Indonesia: Stabilizing he Exchange Rate along Its Fundamental. Bank of International Settlement Papers No.73.

23 Ibid.
} 
in maintaining the objective of flexible exchange rate:

1. Exchange rate policy should be part of the monetary policy as a whole

2. Financial system regulation and prudential must be strengthened to prevent the volatility of exchange rate

3. Credibility of monetary authority should be maintained to be able to influence the market expectation toward the exchange rate path in the future.

4. Capital control policy should be well-managed to maintain the balance between the benefit and potential risk of capital inflow. In this developing stages, Indonesia still need a lot investment, but it is important to make sure those investment are less risky.

\section{Conclusion}

The choice of exchange rate regime is depending on many thing such as size of economy, openness, export structure, geographic concentration, domestic inflation, financial development, labor mobility, capital mobility, foreign and domestic nominal shock and real shocks, and also credulity of policymakers.

Any exchange rate regime, from the hard peg to the independently free floating, are still subject to some problems (on its own) that will hamper the objective the exchange rate policy. Therefore, exchange rate policy should be complemented by another policy, such as capital control, strengthening financial regulation, and fiscal institution.

In case of Indonesia, exchange rate policy is part of monetary policy as whole, which is inflation targeting. It is clear that Indonesia does not adopt the pure free floating exchange rate and do some intervention in foreign exchange market. So, intervention of exchange rate is aiming to maintain the exchange rate along its fundamental value and consistent with the monetary objective to stabilize price level. Up to know, these policy mix are able to achieve price stability and financial stability in the medium and long term. Although in the short term it is difficult to prevent the exchange rate volatility.

\section{Bibliography}

Abdullah, Burhanuddin. 2006. Monetary and Exchange Rate Policy in a Global Financial IntegrationIndonesia Experience. Paper presented at the South East AsiaLatin America and Caribbean Countries

(SEACEN-LAC) Governors Seminar. Kuala Lumpur.

Frieden, Jeffry, Piero Ghezzi, and Ernesto Stein. 2000. Politics and Exchange Rate in Latin America. Research Network Working Paper \#R-42 I. Washington: Inter-American Development Bank.

Garber, Peter M. and Lars E.O Svenson. 1994. The Operation and Collapse of Fixed Exchange Rate Regimes. NBER Working Paper No. 4971. Cambridge.

Goeltom, Miranda S. Capital Flows in Indonesia: Challenges and Policy Responses. Bank of International Settlement Papers No. 44

Hernandez, Leonardo and Peter J. Montiel. 2001. Post-Crisis Exchange Rate Policy in Five Asian Countries: Filling in the "Hollow Middle'? Paper for High Level Seminar "Exchange Rate Regimes: Hard Peg or Free Floating", Washington: IMF Institute.

IMF. De Facto Classification of Exchange Rate and Monetary Framework. http://www.imf.org/external/n $\mathrm{p} / \mathrm{mfd} / \mathrm{er} / 2006 / \mathrm{eng} / 0706 . \mathrm{htm}$

Mundell , Robert A. 1999. Exchange-Rate Arrangements in the Transition Economies. Balance of Payment, Exchange Rates, and Competitiveness in Transition Economies, ed. Mario I. Blejer and Marko Skreb. Boston: Kluer Academic Publishers:. 
Ohta, Hideaki. 2012. Capital Account Liberalization and Control in Indonesia-Effectiveness of Controls in the Real Economy and Monetary/Financial Sector. The $13^{\text {th }} \quad$ International Convention of the East Asian Economic Association, Singapore.

Rana, Pradumna B. 1998. The East Asian Financial Crisis-Implication for Exchange Rate Management. Economics and Development
Resources Center Briefing Notes No.5, Asian Development Bank. Velasco, Andres. 2000. Exchange Rate Policies for Developing Countries: What Have We Learned? What Do We Still Not Know? G-24 Discussion Paper No.5. New York: United Nation.

Warjiyo, Perry. Indonesia: Stabilizing he Exchange Rate along Its Fundamental. Bank of International Settlement Papers No.73.

\begin{tabular}{|c|c|c|}
\hline Date & Changes to the exchange rate regime & $\begin{array}{l}\text { Indonesian } \\
\text { Rupiah per } \\
\text { U.S. Dollar }\end{array}$ \\
\hline $\begin{array}{c}17 \text { April } \\
1970\end{array}$ & $\begin{array}{l}\text { The Indonesian Rupiah (Rp) was devalued to a new Flexible General } \\
\text { Exchange Rate, or Devisa Umum (DU), of Rp378.00 per U.S. Dollar. } \\
\text { A subsidiary Flexible Credit Foreign Exchange Rate, or Devisa Kredit (DK), } \\
\text { of Rp326.00 per U.S. Dollar was created. } \\
\text { These changes represented a simplification and merging the multiple } \\
\text { exchange system of the Export Bonus (BE) Certificate Rate and the } \\
\text { Complementary Foreign Exchange (DP) Rate, and formed the basis of the } \\
\text { exchange rate structure. (WCY 1984, p.357) } \\
\text { The } 10 \% \text { exchange tax on export proceeds was introduced. }\end{array}$ & 378.000 \\
\hline $\begin{array}{l}10 \\
\text { December } \\
1970\end{array}$ & $\begin{array}{l}\text { The exchange rate was unified by the elimination of the Flexible Credit } \\
\text { Foreign Exchange Rate (DK). The Flexible General Exchange (DU) Rate } \\
\text { became applicable to all exchange transactions. (WCY 1984, p.357) }\end{array}$ & \\
\hline $\begin{array}{l}23 \text { August } \\
1971\end{array}$ & $\begin{array}{l}\text { Following the floating of the U.S. Dollar on } 15 \text { August } 1971 \text {, the Rupiah was } \\
\text { devalued } 8.9 \% \text { in terms of gold from Rp378.00 to Rp415.00 per American } \\
\text { unit. } \\
\text { The Flexible Credit Foreign Exchange (DK) Rate was reintroduced, creating } \\
\text { a multiple exchange rate structure. (WCY 1984, p.357) } \\
\text { In the Jakarta foreign exchange Bourse, transactions in U.S. Dollars had } \\
\text { been effected at the rate within 1\% either side of Rp415 per U.S. Dollar. } \\
\text { (IMF 1976, p.235) }\end{array}$ & 415.000 \\
\hline $\begin{array}{l}20 \\
\text { December } \\
1971\end{array}$ & $\begin{array}{l}\text { The gold content of Rupiah reduced by } 7.89 \% \text { because of devaluation of U.S. } \\
\text { Dollar. (WCY 1984, p.357) }\end{array}$ & \\
\hline $\begin{array}{l}14 \\
\text { February } \\
1973\end{array}$ & $\begin{array}{l}\text { Indonesia announced that the Official Rate, or Flexible General Foreign } \\
\text { Exchange (DU) Rate, of Rp } 415.00 \text { per U.S. Dollar would remain unchanged, } \\
\text { Rupiah devaluated by } 10 \% \text { in terms of gold. (WCY 1984, p.357) }\end{array}$ & \\
\hline $\begin{array}{l}12 \text { June } \\
1974\end{array}$ & $\begin{array}{l}\text { The } 10 \% \text { exchange tax on export proceeds was replaced by a } 10 \% \text { tax on } \\
\text { the export value of most shipments abroad, retaining the Export Rate of } \\
\text { Rp374.00 per U.S. Dollar. (WCY 1984, p.357) }\end{array}$ & \\
\hline $\begin{array}{l}\text { 1 April } \\
1976\end{array}$ & $\begin{array}{l}\text { The export tax was changed to } 5 \%-10 \% \text { depending on commodity. (WCY } \\
1984, \text { p.357) }\end{array}$ & \\
\hline $\begin{array}{l}16 \\
\text { November } \\
1978\end{array}$ & $\begin{array}{l}\text { The Flexible Credit Foreign Exchange (DK) Rate was abolished. (WCY 1984, } \\
\text { p.357) } \\
\text { The exchange rate of the Rupiah was depreciated by 33.6\%, adjusted from } \\
\text { Rp415.00 to Rp625.00 per U.S. Dollar. At the same time, the Rupiah's link to } \\
\text { the U.S. Dollar was severed and the Bank Indonesia had set the middle rate } \\
\text { each day using a basket of currencies of Indonesia's main trading partners } \\
\text { as one of the variables. }\end{array}$ & 625.000 \\
\hline
\end{tabular}




\begin{tabular}{|c|c|c|}
\hline & $\begin{array}{l}\text { An Effective Rate was established on a controlled, floating basis. } \\
\text { Transactions in the Jakarta Foreign Exchange Bourse were effected at rates } \\
\text { within } 1 \% \text { either side of the middle rate of the Rupiah. (IMF 1979, p.212) }\end{array}$ & \\
\hline $\begin{array}{l}29 \text { January } \\
1979\end{array}$ & $\begin{array}{l}\text { The facility given to foreign exchange banks to conclude swap transactions } \\
\text { with Bank Indonesia was extended to include nonbank financial } \\
\text { institutions. Each foreign exchange bank and nonbank financial institution } \\
\text { was subject to a ceiling set by Bank Indonesia. (IMF 1980, p.202) }\end{array}$ & \\
\hline $\begin{array}{l}4 \text { August } \\
1979\end{array}$ & An additional export tax of $20 \%$ was established. (WCY 1984, p.357) & \\
\hline $\begin{array}{l}30 \text { March } \\
1983\end{array}$ & $\begin{array}{l}\text { The effective Rate for the Indonesian Rupiah was depreciated } 27.6 \% \text {, from } \\
\text { Rp702 to Rp970 per U.S. Dollar. (Prawiro, p.223) } \\
\text { Bank Indonesia announced that it would continue to follow a policy of } \\
\text { managed float, and would consider a broader set of currencies in } \\
\text { determining the exchange rate of Rupiah. (IMF 1984, p.260) }\end{array}$ & \\
\hline $\begin{array}{l}1 \text { January } \\
1984\end{array}$ & The MPO tax on imports and exports was abolished. (WCY 1985, p.401) & \\
\hline $\begin{array}{l}12 \\
\text { September } \\
1986\end{array}$ & $\begin{array}{l}\text { The Effective Rate for the Rupiah was devalued 31\% in terms of U.S. Dollar. } \\
\text { It was changed from Rp1134 to Rp1664.00 per U.S. Dollar. (IMF 1987, } \\
\text { p.277) }\end{array}$ & $1,664.000$ \\
\hline $\begin{array}{l}24 \text { October } \\
1986\end{array}$ & $\begin{array}{l}\text { Five export taxes were fixed at } 0 \%, 5 \%, 10 \%, 20 \% \text { and } 30 \% \text {, with the } \\
\text { provision that certain exports were subject to an extra export tax. (IMF } \\
\text { 1987, p.278) }\end{array}$ & \\
\hline $\begin{array}{l}25 \text { October } \\
1986\end{array}$ & $\begin{array}{l}\text { The ceiling on foreign currency swaps between commercial banks and } \\
\text { Bank Indonesia was lifted. However, the amount of swap must not exceed } \\
\text { the foreign loan received by the commercial bank. The premium on the } \\
\text { swap was set by the Bank Indonesia at the fixed rate of } 9 \% \text {. (IMF 1987, } \\
\text { p.278) }\end{array}$ & \\
\hline $\begin{array}{l}27 \text { October } \\
1988\end{array}$ & $\begin{array}{l}\text { The premium applicable to operations under the official swap facility } \\
\text { would be set according to the difference between the average domestic } \\
\text { deposit rate and LIBOR for the relevant period. For swap transactions with } \\
\text { maturities exceeding } 1 \text { year, the premium would be established only for the } \\
\text { first } 12 \text { months. The Government would not provide any commitment on } \\
\text { the size of the premium for the subsequent period. (IMF 1989, p.237) }\end{array}$ & \\
\hline $\begin{array}{l}31 \text { March } \\
1989\end{array}$ & $\begin{array}{l}\text { Following the IMF classification, Indonesia was classified under managed } \\
\text { floating. (Ariff, p.155) }\end{array}$ & \\
\hline $\begin{array}{l}30 \text { April } \\
1989\end{array}$ & $\begin{array}{l}\text { Foreign exchange banks were required to limit their daily net open position } \\
\text { on foreign exchange to less than } 25 \% \text { of their own capital. Banks exceed } \\
\text { this limit on net open position would be subject to a sanction. } \\
\text { Controls on foreign exchange banks' offshore borrowing, which was } \\
\text { previously subject to approval by Bank Indonesia, were lifted. (IMF 1990, } \\
\text { p.234) }\end{array}$ & \\
\hline $\begin{array}{l}16 \\
\text { September } \\
1989\end{array}$ & $\begin{array}{l}\text { The exchange rate system was revised. The Effective Rate, based on a } \\
\text { managed float, would apply only to certain transactions undertaken at } \\
\text { certain times of the day. An Interbank Free Rate, which was determined } \\
\text { between banks, would govern all other transactions. (WCY 1990/93, } \\
\text { p.439) }\end{array}$ & \\
\hline $\begin{array}{l}1 \text { March } \\
1991\end{array}$ & $\begin{array}{l}\text { Bank Indonesia ceased to accept swaps for one-month and shorter } \\
\text { maturities, and reduced banks' overall limits to } 20 \% \text { from } 25 \% \text { of capital. } \\
\text { (IMF 1992, p.234) }\end{array}$ & \\
\hline $\begin{array}{l}1 \\
\text { November } \\
1991\end{array}$ & $\begin{array}{l}\text { Banks were required to keep the net open position in foreign currency } \\
\text { including their off-balance-sheet accounts at or below } 20 \% \text { of capital. } \\
\text { The swap facility was modified. Two categories of swaps were created: } \\
\text { liquidity swaps (with maturities of up to } 2 \text { years) and investment swaps } \\
\text { (with 2-3 years' maturities). } \\
\text { Bank Indonesia gave up the obligation to accept swaps with maturities of } \\
\text { less than } 2 \text { years. (IMF 1992, p.234) }\end{array}$ & \\
\hline $\begin{array}{l}16 \\
\text { September } \\
1992\end{array}$ & $\begin{array}{l}\text { The Central Bank increased the spread between its buying and selling rates } \\
\text { for the U.S. Dollar to Rp10 from Rp6 per U.S. Dollar. (WCY 1990/93, p.439) }\end{array}$ & \\
\hline
\end{tabular}




\begin{tabular}{|c|c|}
\hline $\begin{array}{l}1 \\
\text { November } \\
1993\end{array}$ & $\begin{array}{l}\text { The exchange rate in Bank Indonesia's daily squaring session in the } \\
\text { afternoon was allowed to deviate from the indicative rate posted in the } \\
\text { morning by Rp2 a day (previously, the deviation was allowed up to Rp1 a } \\
\text { day). (IMF 1994, p.240) }\end{array}$ \\
\hline $\begin{array}{l}6 \\
\text { September } \\
1994\end{array}$ & $\begin{array}{l}\text { Bank Indonesia announced daily buying and selling rates that were } \\
\text { computed on the basis of a basket of weighted currencies with a spread of } \\
\text { plus or minus Rp15. } \\
\text { The limits on banks' open positions were liberalized, banks were required } \\
\text { to meet a net open position of } 25 \% \text { of capital instead of } 20 \% \text {, and the open } \\
\text { position requirement would no longer apply to individual currencies. (IMF } \\
\text { 1995, p.238) }\end{array}$ \\
\hline $\begin{array}{l}30 \text { June } \\
1995\end{array}$ & $\begin{array}{l}\text { Bank Indonesia announced that buying and selling rates computed on the } \\
\text { basis of a basket of weighted currencies with a spread of plus or minus } \\
\text { Rp22. (IMF 1996, p.237) }\end{array}$ \\
\hline $\begin{array}{l}17 \text { July } \\
1995\end{array}$ & $\begin{array}{l}\text { Bank Indonesia terminated the provision of investment swaps. (IMF 1996, } \\
\text { p.237) }\end{array}$ \\
\hline $\begin{array}{l}1 \text { January } \\
1996\end{array}$ & $\begin{array}{l}\text { The Bank Indonesia (BI) within a system of managed float determined the } \\
\text { exchange rate. The system was based on a daily announcement of } \\
\text { "conversion rate band" (for official transactions with foreign exchange } \\
\text { banks, the government and supranational institutions), and an } \\
\text { "intervention band" (consisted of buying and selling rates that were } \\
\text { computed on the basis of a basket of currencies). (IMF 1998, p.433) }\end{array}$ \\
\hline $\begin{array}{l}13 \text { June } \\
1996\end{array}$ & $\begin{array}{l}\text { The spread of the intervention band was increased to Rp118 (5\%) from } \\
\text { Rp66. (IMF 1997, p.403) }\end{array}$ \\
\hline $\begin{array}{l}10 \\
\text { September } \\
1996\end{array}$ & $\begin{array}{l}\text { The spread of the intervention band was increased to Rp192, } \\
\text { approximately } 8 \% \text {. (IMF 1997, p.403) }\end{array}$ \\
\hline $\begin{array}{c}11 \text { July } \\
1997\end{array}$ & The intervention band was widening to $12 \%$ from $8 \%$. (IMF 1998, p.433) \\
\hline $\begin{array}{l}14 \text { August } \\
1997\end{array}$ & $\begin{array}{l}\text { The managed floating exchange regime was replaced by a free- floating } \\
\text { exchange rate arrangement. (IMF 1998, p.439) }\end{array}$ \\
\hline $\begin{array}{l}28 \\
\text { February } \\
1998\end{array}$ & $\begin{array}{l}\text { A foreign exchange subsidy for food was introduced, which led to the } \\
\text { reclassification of the exchange rate system from unitary to dual. (IMF } \\
1999, \text { p.422) }\end{array}$ \\
\hline
\end{tabular}

Source: Historical Exchanger Rate Regime in Asian Countries http://intl.econ.cuhk.edu.hk/exchange rate regime/index.php?cid=6 
Table 1: Capital and foreign exchange liberalization and controls (Indonesia)

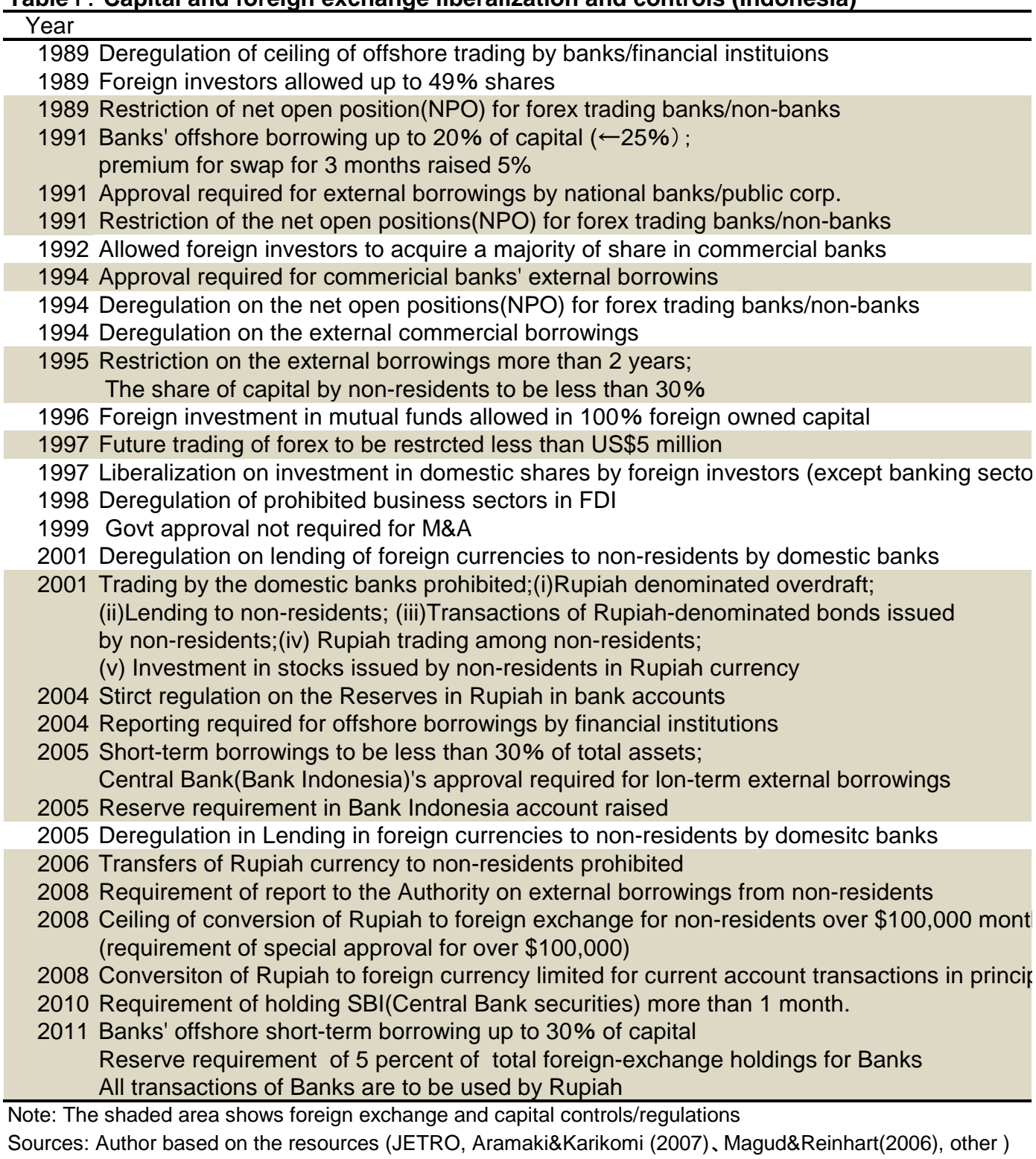


